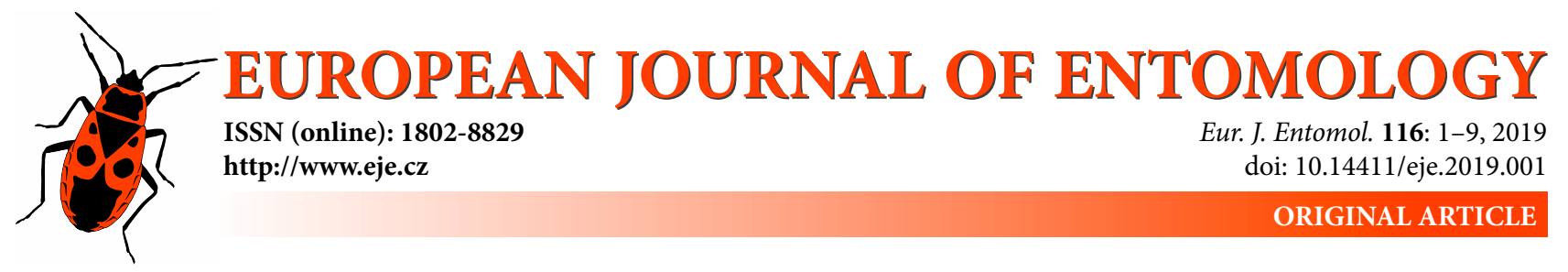

\title{
Effects of temperature on the activity of antioxidant enzymes in larvae of Bactrocera dorsalis (Diptera: Tephritidae) parasitized by Diachasmimorpha longicaudata (Hymenoptera: Braconidae): Optimizing the mass rearing of this braconid by varying the temperature
}

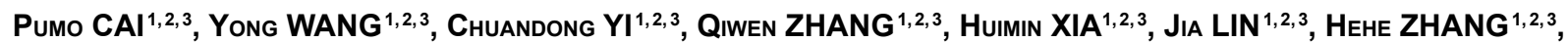 \\ JIANQUAN YANG ${ }^{1,2,3}$, QINGE $\mathrm{JI}^{1,2,3, *}$ \& JIAHUA CHEN ${ }^{1,2,3}$ \\ ${ }^{1}$ Institute of Beneficial Insects, Plant Protection College, Fujian Agriculture and Forestry University, 350002 Fuzhou, P.R. \\ China; e-mails: caipumo@qq.com, 1506293481@qq.com, 602328593@qq.com, 344463987@qq.com, 523441201@qq.com, \\ 776954169@qq.com, zhh680216@163.com, 2576680960@qq.com, jiqinge@yeah.net, jhchen34@yeah.net \\ ${ }^{2}$ State Key Laboratory of Ecological Pest Control for Fujian and Taiwan Crops, 350002 Fuzhou, P.R. China \\ ${ }^{3}$ Key Lab of Biopesticide and Chemical Biology, Ministry of Education, 350002 Fuzhou, P.R. China
}

Key words. Diptera, Tephritidae, Bactrocera dorsalis, Hymenoptera, Braconidae, Diachasmimorpha longicaudata, parasitoid, altering temperatures, mass-reared, activity of antioxidants

\begin{abstract}
Diachasmimorpha longicaudata is the most widely used endoparasitoid in biocontrol programmes against various species of tephritids and is continuously mass-reared under laboratory conditions at a constant temperature; however, little is known about how varying the temperature might affect the effectiveness of the mass rearing of immature $D$. longicaudata. This study aimed to determine the optimum temperature for the development of larvae $D$. longicaudata the larvae of its host, Bactrocera dorsalis. Third-instar $B$. dorsalis were exposed for $4 \mathrm{~h}$ to five pairs of parasitoids, and then they were kept at one of six temperatures ranging from $19^{\circ} \mathrm{C}$ to $34^{\circ} \mathrm{C}$. The activities of three major antioxidant enzymes (CAT, POX, SOD) were individually measured 4,24 , 48 and $72 \mathrm{~h}$ after exposure to each of the six temperatures. The results were as follows: for CAT the highest CAT activities were recorded at $25^{\circ} \mathrm{C}$ (intervals $5-24 \mathrm{~h}$ and $25-48 \mathrm{~h}$ ), at $28^{\circ} \mathrm{C}$ (interval $0-4 \mathrm{~h}$ ) and at $31^{\circ} \mathrm{C}$ (interval $49-72 \mathrm{~h}$ ), and for POX and SOD identically at $25^{\circ} \mathrm{C}$ (intervals $0-4 \mathrm{~h}, 5-24 \mathrm{~h}$ ) and at $31^{\circ} \mathrm{C}$ (intervals $25-48 \mathrm{~h}, 49-72 \mathrm{~h}$ ), respectively. Subsequently, the effects keeping the parasitized larvae at these different temperatures on the biological attributes of $D$. longicaudata reared under laboratory conditions were investigated. The percentage of their eggs that hatched, percentage of adults that emerged, pupal weight and longevity were significantly greater than that recorded for the control when the parasitized host larvae were kept at $28^{\circ} \mathrm{C}$ for $4 \mathrm{~h}$, $25^{\circ} \mathrm{C}$ for 5 and $48 \mathrm{~h}$ and $31^{\circ} \mathrm{C}$ for 49 and $72 \mathrm{~h}$.
\end{abstract}

\section{INTRODUCTION}

The oriental fruit fly Bactrocera dorsalis (Hendel) (Diptera: Tephritidae) is a generalist pest that feeds on more than 270 species of host plants in 46 different families of plants throughout tropical and subtropical Asia (Allwood \& Chinajariyawong, 1999; Clarke et al., 2001; Vargas et al., 2007). This species is a devastating pest of carambola, peach, jujube, citrus, loquat, guava, lychee, longan and other tropical and subtropical crops, causing significant yield and financial losses in southern China (Ji et al., 2016). Thus, its control and management are of great socioeconomic significance. Great efforts were made over the last several decades to develop effective means of controlling $B$. dorsalis, however, in China, the control of this pest depends mainly on the use of chemical insecticides (Zhang et al., 2014). The use of wide-spectrum chemical pesticides results in many secondary problems, such as environmental pollution, decreases in the abundance of natural enemies, presence of chemical residues in foods and resistance of this pest to pesticides (Zhang et al., 2014; Cai et al., 2017).

Due to the ineffectiveness and undesirable consequences of using pesticides, parasitoid species, such as Fopius arisanus (Sonan), Psyttalia incisi (Silvestri), Fopius vandenboschi (Fullaway) and Diachasmimorpha longicaudata (Ashmead) (Hymenoptera: Braconidae), have been widely used to depress fruit fly populations in many regions (Vargas et al., 1993, 2012; Cai et al., 2017; Yang et al., 2018). Among the fruit fly parasitoids available for augmentative release in Fujian Province of China, D. longicaudata is the most reliable (Cai et al., 2018a).

\footnotetext{
* Corresponding author; e-mail: jiqinge@yeah.net
} 
Native to Southeast Asia, D. longicaudata is a koinobiont endoparasitoid that has been widely used in biological control programmes against tephritid fruit flies, including B. dorsalis, in southern China (Liu et al., 2012; Segura et al., 2016; Simmonds et al., 2016). D. longicaudata can become established in various environments and is amenable to mass rearing in the larvae of several species of the genus Bactrocera (Wharton \& Gilstrap, 1983; Baranowski et al., 1993; Chinajariyawong et al., 2000). The role of D. longicaudata in biological pest control programmes has stimulated research into various aspects of its biology, such as conditions for mass rearing and release, molecular biology and physiology, in order to improve its use in agriculture pest management (Constanza et al., 2016; Costa et al., 2016; Ndlela et al., 2016; Simmonds et al., 2016; Julsirikul et al., 2017).

Evaluation of the optimum temperature for development of a parasitoid is an important step in its mass production under laboratory conditions and inundative release in the field and a basic requirement of any biological pest control programme (Meirelles et al., 2015). Temperature is one of the most important climatic factors influencing the distribution, abundance, immature development, adult emergence, fecundity, longevity and parasitism capability of egg parasitoids (Maceda et al., 2003; Liu et al., 2012). The effectiveness of biological control programmes can be limited by adverse climatic conditions (Firake \& Khan, 2014). The effects of temperature on D. longicaudata developing in different hosts is well studied; for instance, Meirelles et al. $(2013,2015)$ report that rapid development of D. longicaudata in Anastrepha fraterculus (Wiedemann) and Ceratitis capitata (Wiedemann) (Diptera: Tephritidae) is achieved at a constant temperature of $25^{\circ} \mathrm{C}$. Liu et al. (2012) suggest that the most appropriate temperature range for the reproduction and development of $D$. longicaudata adults that developed as larvae in B. dorsalis is from 24 to $27^{\circ} \mathrm{C}$. These previous studies investigated the effects of constant temperatures (Liu et al., 2012; Meirelles et al., 2013, 2015). However, parasitoids reared under constant laboratory conditions for a long period can upon release be adversely affected by different temperatures, which can influence their effectiveness as biological control agents (Firake \& Khan, 2014).

To counter this, it is necessary to acclimatize the parasitoids to temperature fluctuations during rearing in the laboratory. The effects of varying the temperature on adults of D. longicaudata are well studied (Liu et al., 2012; Meirelles et al., 2013, 2015), however, its effect on immature stages is often ignored. The basic daily thermal requirements of larvae of $D$. longicaudata developing within host larvae were evaluated based on the effects of varying the temperature on the levels of three major antioxidant enzymes in parasitized larvae of $B$. dorsalis at different stages in their development.

In healthy animals, a balance exists between the production of reactive oxygen species (ROS) and antioxidant processes. However, various types of stress, e.g., thermal stress and parasitization, can disrupt the antioxidant system and induce oxidative stress (Carton et al., 2008; LopezMartinez et al., 2008). The overexpression of ROS in the form of the superoxide $\left(\mathrm{O}_{2}^{-}\right)$, hydroxyl radicals $\left(\mathrm{OH}^{-}\right)$, hydrogen peroxide $\left(\mathrm{H}_{2} \mathrm{O}_{2}\right)$ and singlet oxygen $\left({ }^{1} \mathrm{O}_{2}\right)$ can result in an increase in protein oxidation, DNA damage and lipid peroxidation (LPO), which may lead to apoptosis due to enzyme inactivity and membrane damage (Livingstone, 2001; Yang et al., 2010). To maintain homeostasis and prevent oxidative damage, insects have evolved a complex enzymatic and non-enzymatic defence system to mitigate oxidative stress. The main antioxidant enzymes in insects are superoxide dismutase (SOD), catalase (CAT) and peroxidases (POX) (Dubovskiy et al., 2008; Ali et al., 2017). SOD breaks down superoxide radicals into oxygen and $\mathrm{H}_{2} \mathrm{O}_{2}$, whereas both CAT and POX convert $\mathrm{H}_{2} \mathrm{O}_{2}$ into oxygen and water (Yang et al., 2010). A significant increase in the activity of the antioxidant enzymes, CAT, POX and SOD is a sign of oxidative stress and an indicator of the ability of insects to combat oxidative stress by cooperatively eliminating the oxidative stress resulting from the high concentrations of ROS in cells (Jia et al., 2011; Cai et al., 2018b).

Previous studies have indicated that at a constant temperature the activity of POX in larvae of $B$. dorsalis is significantly increased by infection with $P$. incisi (Liang et al., 2007). CAT, POX and SOD, together, have an important role in preventing the larvae of $B$. dorsalis suffering from oxidative damage induced by parasitization by $D$. longicaudata (Wang et al., 2013). The effects of different temperatures on the adults of $B$. dorsalis indicate it is likely that these three main antioxidant enzymes have an important role in reducing oxidative stress induced by thermal stress (Jia et al., 2011). Nevertheless, there are few studies on the effects of different temperatures on parasitized agriculture pests. In this study, we determined the effects of temperature on the three main antioxidant enzymes in parasitized larvae of $B$. dorsalis after different periods of time in order to determine the most appropriate thermal strategy for rearing parasitized hosts and their parasitoid progeny. Subsequently, the effects of different temperatures on the biological attributes of $D$. longicaudata reared under laboratory conditions were determined. This study aimed at increasing the efficiency of the mass-rearing of D. longicaudata and the performance of this parasitoid in the field by varying the temperature at which the immature stages of this parasitoid were reared.

\section{METHODS}

\subsection{Insects}

Colonies of $B$. dorsalis and D. longicaudata were established initially by collecting rotten citrus fruit infested with $B$. dorsalis from an orchard in Zhangzhou city, Fujian, China, and then reared in the Beneficial Insects Institute of Fujian Agriculture and Forestry University (BII, FAFU), Fuzhou, Fujian, China, in accordance with the procedures reported by Spencer \& Fujita (1997) and Shao et al. (2008). The B. dorsalis larvae were cultured on an artificial diet based on a mixture of torula yeast, wheat bran, sugar, sodium benzoate, nipagin and water in fixed proportions. The adult flies were kept in a cage $(30 \times 30 \times 30 \mathrm{~cm})$ under 
controlled conditions at $25 \pm 1{ }^{\circ} \mathrm{C}, 65 \pm 5 \%$ relative humidity and a photoperiod of $12 \mathrm{~L}: 12 \mathrm{D}$, and provided with water and a mixture of torula yeast and sugar. The D. longicaudata were reared in third-instar larvae of $B$. dorsalis, and the parasitoid adults were fed a $10 \%$ honey solution in a Hawaii-type cage (Wong \& Ramadan, 1992) $(30 \times 30 \times 30 \mathrm{~cm})$ under the same laboratory conditions as above.

\subsection{Experiments}

\subsubsection{Experiment I: Effects of temperature on the activity} of the three main antioxidant enzymes in parasitized larvae of $B$. dorsalis

\subsubsection{Parasitization by $D$. longicaudata}

When the larvae of $B$. dorsalis reached the third stage (five days after collecting the eggs), they were transferred from the artificial diet to an oviposition unit consisting of a Petri dish with a mesh top (height: $0.5 \mathrm{~cm}$; diameter: $6 \mathrm{~cm}$, Aluja et al., 2009). Each oviposition unit contained a small amount of larval diet and a random sample of 100 larvae. Then, the oviposition units were placed in cages and exposed to five pairs of 7-day-old virgin parasitoids (female : male $=1: 1$ ) for $4 \mathrm{~h}$ at a constant temperature of $25^{\circ} \mathrm{C}$. To reduce superparasitism by $D$. longicaudata, the ratio of female parasitoids to fruit flies was 20 to 1 (Lin et al., 2006). After $4 \mathrm{~h}$ of exposure, the larvae were placed on larval diet on a plate $(4 \times 10 \times 20 \mathrm{~cm})$. Based on the reported optimum temperature for adults of $D$. longicaudata (Liu et al., 2012), six temperatures ranging from $19^{\circ} \mathrm{C}$ to $34^{\circ} \mathrm{C}$ were selected for rearing parasitized larvae of $B$. dorsalis. Then each of the plates was placed in one of six climatic cabinets that were each set at either $19^{\circ} \mathrm{C}$, $22^{\circ} \mathrm{C}, 25^{\circ} \mathrm{C}, 28^{\circ} \mathrm{C}, 31^{\circ} \mathrm{C}$ or $34^{\circ} \mathrm{C}(\mathrm{PRX}-80 \mathrm{~A}$, Shanghai Joe Yue Electronics Co. Ltd., Shanghai, China), respectively. A constant humidity $(70 \%)$ and photoperiod (12L:12D) were maintained throughout this experiment, which was repeated three times. The group subjected to a constant temperature of $25^{\circ} \mathrm{C}$ was treated as the control.

\subsubsection{Sample preparation}

Four hours after parasitization, five live parasitized $B$. dorsalis larvae from each treatment were selected at random and washed more than three times using distilled water. The parasitoid larvae were quickly removed from the host larvae using a dissecting needle under a microscope. To eliminate potential confounding effects of superparasitism, host larvae that contained more than one parasitoid larva were excluded from the assays. After dissection, the remains of the bodies of the $B$. dorsalis larvae were immediately frozen in liquid nitrogen and stored at $-80^{\circ} \mathrm{C}$ until analyzed, and the remaining $B$. dorsalis larvae were returned to their respective climatic cabinets to continue their development. This was repeated 24,48 and $72 \mathrm{~h}$ after parasitization.

\subsubsection{Protein extraction}

Total protein was extracted from samples using commercially available kits from Shanghai Lanji Bioengineering Institute (Shanghai, China) following the manufacturer's instructions. Prepared fruit fly samples were first homogenized in $2 \mathrm{~mL}$ of icecold $0.05 \mathrm{M} \mathrm{pH} 7.0$ phosphate buffer (PB). The crude homogenates were centrifuged at $8000 \mathrm{r} / \mathrm{min}$ for $10 \mathrm{~min}$ at $4{ }^{\circ} \mathrm{C}$, and the supernatant was used for further analysis. Protein concentrations were evaluated in accordance with the Bradford (1976) method using serum albumin as the standard.

\subsubsection{The antioxidant enzyme activity assay}

The activities of CAT, POX and SOD were evaluated based on the protocols of the commercially available assay kits used (Shanghai Lanji Bioengineering Institute, Shanghai, China).
Absorbance was read using a microplate spectrophotometer (UV2900, Sunny Optical Technology Co., Ltd., China).

CAT activity was calculated by determining the decrease in absorbance at $230 \mathrm{~nm}$ due to $\mathrm{H}_{2} \mathrm{O}_{2}$ decomposition (Luck, 1971). One unit of CAT activity was defined as the amount of $\mathrm{H}_{2} \mathrm{O}_{2}$ decomposed per second per gram of protein. CAT activity was expressed as $\mathrm{U} \mathrm{g}^{-1}$ protein.

The POX activity was calculated spectrophotometrically at 470 $\mathrm{nm}$ based on the catalysis of oxidation in the presence of $\mathrm{H}_{2} \mathrm{O}_{2}$ (Reddy et al., 1985). One unit of POX activity was described as the amount that catalyses $1 \mu \mathrm{g}$ of substrate in one minute per milligram of protein. POX activity was expressed as $\mathrm{U} \mathrm{g}^{-1}$ protein.

The SOD activity was calculated at $560 \mathrm{~nm}$ using xanthine and xanthine oxidase systems (Marklund \& Marklund, 1974). One unit of SOD activity was defined as the amount of enzyme required to decrease the xanthine and xanthine oxidase system reaction in $1 \mathrm{mg} / \mathrm{mL}$ protein extract by $50 \%$. SOD activity was expressed as $\mathrm{U} \mathrm{mg}^{-1}$ protein.

\subsubsection{Experiment II: Effects of different temperatures on biological attributes of $D$. longicaudata}

When the adults of $B$. dorsalis in the laboratory colony were sexually mature (10 days after emergence), their eggs were collected using a bottle containing orange juice and then uniformly distributed on the larval diet and reared under constant conditions (temperature, $25^{\circ} \mathrm{C}$; humidity, $70 \%$; photoperiod, $12 \mathrm{~L}$ : $12 \mathrm{D}$ ) until exposed to $D$. longicaudata. After the eggs were collected they were incubated for five days (the third-instar larvae), then a random sample of 100 larvae was transferred from the artificial diet to an oviposition unit with a mesh top; each unit contained a small amount of larval diet (height: $0.5 \mathrm{~cm}$; diameter: $6 \mathrm{~cm}$, Aluja et al., 2009). Then, five of these units were placed in a cage and exposed to twenty-five pairs of 7-day-old parasitoids (female : male $=1: 1$ ) for $4 \mathrm{~h}$ under controlled conditions as described above.

After $4 \mathrm{~h}$ of exposure, all the oviposition units were placed in climatic chambers kept at different temperatures (see Table 1). Parasitoids reared at a constant temperature of $25^{\circ} \mathrm{C}$ served as the untreated control. The exposed larvae were transferred to the artificial diet and kept in a box $(4 \times 10 \times 20 \mathrm{~cm})$ at a constant humidity $(70 \%)$ and photoperiod $(12 \mathrm{~L}: 12 \mathrm{D})$ throughout the evaluation. After the temperature treatments, a random sample of 50 larvae were dissected to check the percentage of the parasitoid eggs that hatched, which was calculated as the number of eggs that hatched divided by the number of parasitized larvae $\times 100$. This experiment was replicated three times.

Then, the incubation boxes with the remaining larvae were transferred from the climatic chambers into larger boxes with mesh tops $(10 \times 30 \times 50 \mathrm{~cm})$ and kept under constant conditions of temperature, $25^{\circ} \mathrm{C}$ humidity $70 \%$ and photoperiod, $12 \mathrm{~L}: 12 \mathrm{D}$. Moist sand was spread on the bottoms of the large boxes for the larvae to pupate in. On the sixth day after pupation, random samples of 300 blackening pupae from each treatment were washed and dried at room temperature and then weighed. The weighed pupae were returned to covered Petri dishes for emergence. After

Table 1. The temperatures at which the highest activities of three main antioxidant enzymes were recorded at different intervals of time after parasitization.

\begin{tabular}{lccc}
\hline \multirow{2}{*}{ Interval of time interval $(\mathrm{h})$} & \multicolumn{3}{c}{ Antioxidant enzymes } \\
\cline { 2 - 4 } & CAT & POX & SOD \\
\hline 4 & 28 & 25 & 25 \\
5 and 24 & 25 & 25 & 25 \\
25 and 48 & 25 & 31 & 31 \\
49 and 72 & 31 & 31 & 31
\end{tabular}

The values in the table are degrees Celsius $\left({ }^{\circ} \mathrm{C}\right)$. 


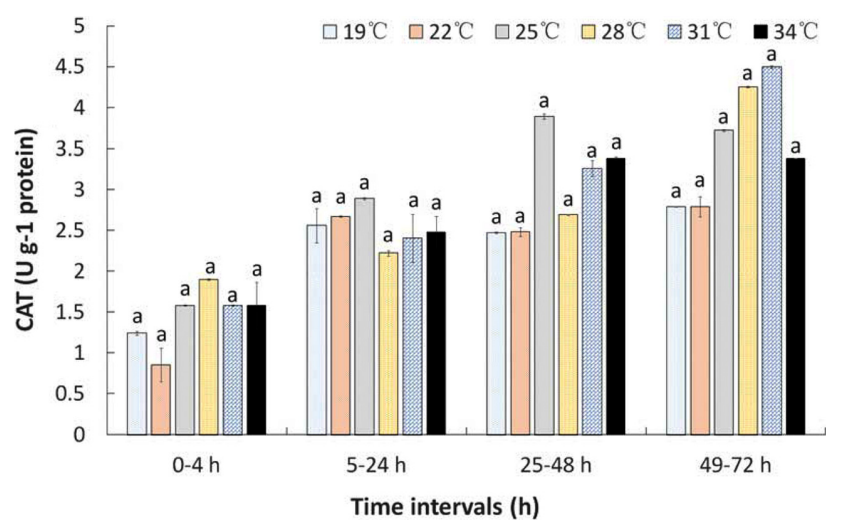

Fig. 1. Catalase (CAT) activity $\left(\mathrm{U} \mathrm{g}^{-1}\right.$ protein) recorded in $B$. dorsalis in the different temperature treatments at different intervals of time after being parasitized by $D$. longicaudata. Each value is the mean $( \pm S E)$ of three replicates. Differences in the letters at the tops of the columns indicate significant differences at $P<0.05$ in ANOVA (LSD test for multiple comparisons).

emergence, the number of adult flies and parasitoids were calculated for each treatment to estimate the percentage emergence and sex ratio. There were three replicates of all treatments. To record longevity, 50 male and 50 female parasitoids from each treatment were placed in a Hawaii-type cage with water and an adult diet consisting of $10 \%$ honey. Mortality was evaluated daily until all parasitoids had died.

\subsection{Statistical analysis}

All statistical procedures were conducted using SPSS 17.0 (SPSS Inc., Chicago, Illinois, USA) and WPS Office 2017 software (Kingsoft Corporation Limited, Beijing, China). The data on enzyme activity recorded in different treatments were subjected to a two-way analysis of variance (ANOVA) (temperature and period) using the general linear model procedure in SPSS 17.0. Average differences were subjected to the least significant difference (LSD) test and considered different the F-values were significant $(\mathrm{P}<0.05)$. The percentage of parasitoid eggs that hatched $(\%)$, pupal weight $(\mathrm{g})$, percentage of the parasitoids that emerged (\%) and sex ratio were analyzed using one-way ANOVA and Tukey's multiple range test with differences considered significant at $\mathrm{P}<$ 0.05 . All percentages were square root transformed to improve normality and homoscedasticity (Zar, 1984), but untransformed means are presented in the figures. Longevity was analyzed using the log-rank test.

\section{RESULTS}

\subsection{Experiment I}

The mortality of oriental fruit fly larvae parasitized by $D$. longicaudata reared at the different temperatures ranged from $13.6 \%$ to $21.6 \%$. Dead fruit fly larvae were excluded from the evaluation.

The statistical analysis revealed that the activity of CAT in parasitized larvae of $B$. dorsalis was significantly affected by temperature $(\mathrm{F}=4.25, \mathrm{df}=5,24 ; \mathrm{P}<0.01)$ and the time for which they exposed to the temperature $(\mathrm{F}=2.75$, $\mathrm{df}=3,24 ; \mathrm{P}<0.01)$. The interaction between temperature and time interval was also significant $(\mathrm{F}=4.59, \mathrm{df}=15,24$; $\mathrm{P}<0.01)$. After $4 \mathrm{~h}$, the activity of CAT in B. dorsalis was not significantly different from those recorded after the other intervals, whereas the activity after this interval of time was lower than after all the other periods and peaked

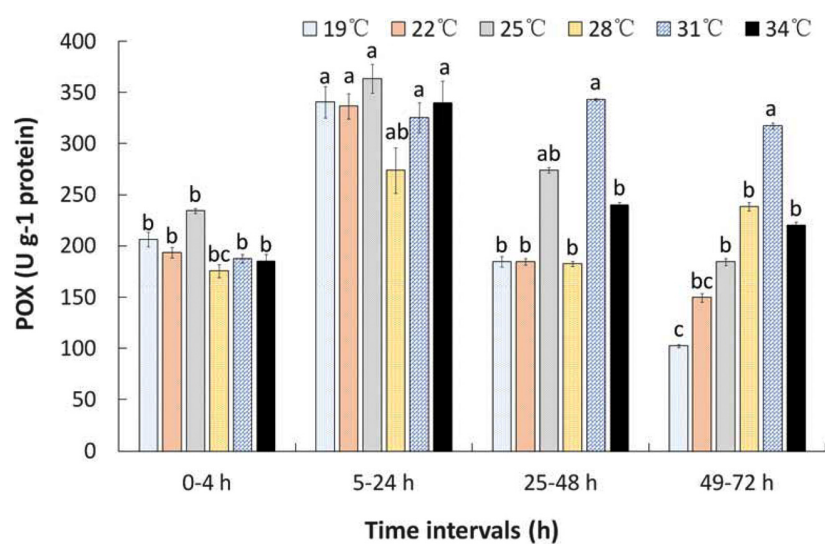

Fig. 2. Peroxidase (POX) activity $\left(\mathrm{U} \mathrm{g}^{-1}\right.$ protein) recorded in $B$. dorsalis in the different temperature treatments at different intervals of time after being parasitized by $D$. longicaudata. Each value is the mean $( \pm S E)$ of three replicate. Differences in the letters at the tops of the columns indicate significant difference at $\mathrm{P}<0.05$ in ANOVA (LSD test for multiple comparisons).

at $28^{\circ} \mathrm{C}$. The activity of CAT recorded after 5 and $24 \mathrm{~h}$, and 25 and $48 \mathrm{~h}$ exhibited similar trends with increase in temperature and both peaked at $25^{\circ} \mathrm{C}$. After $48 \mathrm{~h}$, the activity of CAT was highest at $31^{\circ} \mathrm{C}$ (Fig. 1).

The activity of POX in parasitized larvae of $B$. dorsalis was significantly affected by temperature $(\mathrm{F}=42.14$, $\mathrm{df}=$ $5,24 ; \mathrm{P}<0.01)$ and time interval $(\mathrm{F}=21.74, \mathrm{df}=3,24$; $\mathrm{P}<0.01)$, and there was a significant interaction between temperature and time interval $(\mathrm{F}=14.53, \mathrm{df}=15,24 ; \mathrm{P}$ $<0.01)$. There was a similar trend in the activity of POX with increase in temperature after $4 \mathrm{~h}$ and after 25 and 48 h. The highest values were recorded after $4 \mathrm{~h}$ at $25^{\circ} \mathrm{C}$ and after 25 and $48 \mathrm{~h}$ at $31^{\circ} \mathrm{C}$. For the time intervals of 49 and $72 \mathrm{~h}$, the activity of POX gradually increased with increase in temperature, peaking at $31^{\circ} \mathrm{C}$, and was then less at $34^{\circ} \mathrm{C}$. The activity of POX in $B$. dorsalis was significantly higher after 4 and $24 \mathrm{~h}$ than after other periods of time, except at $28^{\circ} \mathrm{C}$, and peaked at $25^{\circ} \mathrm{C}$ (Fig. 2).

The activity of SOD in parasitized larvae of $B$. dorsalis was significantly enhanced by the different temperature treatments $(\mathrm{F}=52.52$, df $=5,24 ; \mathrm{P}<0.01)$ and after the four time intervals $(\mathrm{F}=34.45, \mathrm{df}=3,24 ; \mathrm{P}<0.01)$. The interaction between temperature and time interval was significant $(\mathrm{F}=25.73$, df $=15,24 ; \mathrm{P}<0.01)$. After $4 \mathrm{~h}$, the activity of SOD in parasitized larvae of $B$. dorsalis was higher than after any of the other time intervals and peaked at $25^{\circ} \mathrm{C}$. The trends in the activity of SOD in parasitized larvae of $B$. dorsalis after 5 and 24 h, 25 and 48 h, and 49 and $72 \mathrm{~h}$ were similar. The highest values were recorded after 5 and $24 \mathrm{~h}$ at $25^{\circ} \mathrm{C}$, after 25 and $48 \mathrm{~h}$ at $31^{\circ} \mathrm{C}$ and after 49 and $72 \mathrm{~h}$ at $31^{\circ} \mathrm{C}$ (Fig. 3). In order to clarify the results of experiment $\mathrm{I}$, the temperatures associated with the highest activities of the three main antioxidant enzymes in parasitized larvae of $B$. dorsalis after the different time intervals are listed in Table 2.

\subsection{Experiment II}

The percentage of eggs that hatched, pupal weight and percentage of the parasitoids that emerged in temperature 


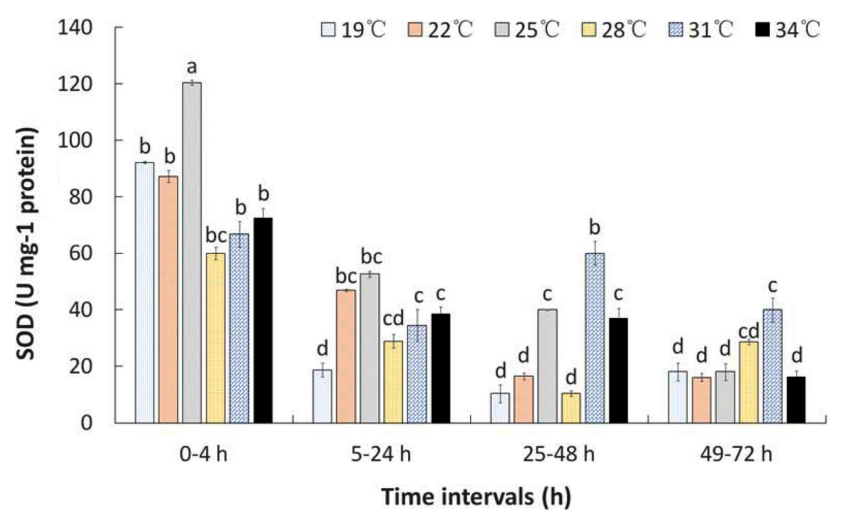

Fig. 3. The activity of superoxid dismutase (SOD) $\left(\mathrm{U} \mathrm{mg}^{-1}\right.$ protein) recorded in $B$. dorsalis in the different temperature treatments at different intervals of time after being parasitized by $D$. longicauda$t a$. Each value is the mean $( \pm S E)$ of three replicates. Differences in the letters at the tops of the columns indicate significant difference at $\mathrm{P}<0.05$ in ANOVA (LSD test for multiple comparisons).

treatment 1 (after $4 \mathrm{~h}$ at $28^{\circ} \mathrm{C}$, after 5 and $48 \mathrm{~h}$ at $25^{\circ} \mathrm{C}$ and after 49 and $72 \mathrm{~h}$ at $31^{\circ} \mathrm{C}$ ) were significantly higher than those recorded in the other treatments, including the control (Percentage egg hatch: $\mathrm{F}=0.56, \mathrm{df}=4, \mathrm{P}<0.05$, Fig. 4; Pupal weight: $F=5.78, \mathrm{df}=4, \mathrm{P}<0.05$, Fig. 5; Percentage parasitoid emergence: $\mathrm{F}=9.15$, df $=4, \mathrm{P}<0.05$, Fig. 6). Significant increases were also recorded in the longevity of male and female parasitoids in temperature treatment 1 (after $4 \mathrm{~h}$ at $28^{\circ} \mathrm{C}$, after 5 and $48 \mathrm{~h}$ at $25^{\circ} \mathrm{C}$, after 49 and $72 \mathrm{~h}$ at $31^{\circ} \mathrm{C}$ ) relative to that recorded in the other treatments (Male: $\chi^{2}=6.95$, df $=4, \mathrm{P}<0.05$; Female: $\chi^{2}=$ 5.72, $\mathrm{df}=4, \mathrm{P}<0.05$, Fig. 8). However, the sex ratio of the parasitoid (female/male) was significantly lower in four of the temperature treatments (after $4 \mathrm{~h}$ at $28^{\circ} \mathrm{C}, 5$ and $48 \mathrm{~h}$ at $25^{\circ} \mathrm{C}, 49$ and $72 \mathrm{~h}$ at $31^{\circ} \mathrm{C}$ ) and 2 treatments (after $48 \mathrm{~h}$ at $25^{\circ} \mathrm{C}, 49$ and $72 \mathrm{~h}$ at $31^{\circ} \mathrm{C}$ ) compared with the control treatment and temperature treatment $4(\mathrm{~F}=423.71, \mathrm{df}=4$, $\mathrm{P}<0.05$, Fig. 7).

\section{DISCUSSION}

The ecological compatibility of a biological control agent is an important aspect of its ability to successfully suppress agriculture pests. The effectiveness of several biological control programmes was negatively affected by adverse environmental conditions. In particular, the variations in temperature during the course of a day strongly affect the performance of parasitoids reared in a laboratory for long periods (Firake \& Khan, 2014). Because laboratory strains

Table 2. The temperatures and duration of exposure experienced by the early developmental stages of Diachasmimorpha longicaudata in each of the temperature treatments.

\begin{tabular}{lcccc}
\hline \multirow{2}{*}{ Temperature treatment } & \multicolumn{4}{c}{ Period $(\mathrm{h})$} \\
\cline { 2 - 5 } & 4 & 5 and 24 & 25 and 48 & 49 and 72 \\
\hline 0 (control) & 25 & 25 & 25 & 25 \\
1 & 28 & 25 & 25 & 31 \\
2 & 25 & 25 & 25 & 31 \\
3 & 28 & 25 & 31 & 31 \\
4 & 25 & 25 & 31 & 31 \\
\hline
\end{tabular}

The values in the table are degrees Celsius $\left({ }^{\circ} \mathrm{C}\right)$.

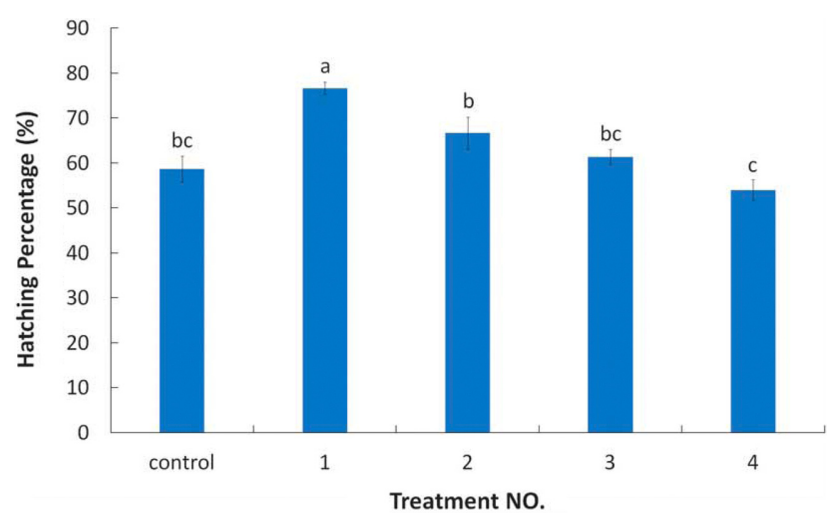

Fig. 4. The percentage of eggs of $D$. longicaudata that hatched in the different temperature treatments. Each value is the mean $( \pm S E)$ of three replicates. Differences in letters at the tops of the columns indicate significant difference at $\mathrm{P}<0.05$ in ANOVA (Tukey test for multiple comparisons).

of parasitoids are usually reared under constant conditions, their effectiveness after release might be affected by the fluctuations in temperature they experience. Determination of the optimal thermal requirement for the development of a parasitoid is a fundamental aspect of biological control programmes against pests and is important for its laboratory production and field release. A previous study indicates that the optimum temperatures for the reproduction and development of adult $D$. longicaudata reared in larvae of $B$. dorsalis range from 24 to $27^{\circ} \mathrm{C}$ (Liu et al., 2012), but previously the effects of temperature on the immature stages of parasitoids were neglected. The activities of three antioxidant enzymes in oriental fruit fly larvae previously parasitized by $D$. longicaudata were considered to be a measure of the ability of parasitized hosts to simultaneously combat two different challenges, specifically, parasitization and variations in temperature. Therefore, we studied the physiological responses of larvae of $B$. dorsalis and their parasitoids to keeping them at different temperatures for different periods of time.

A previous study indicates that the activity of SOD induced by varying the temperature protect fruit flies from

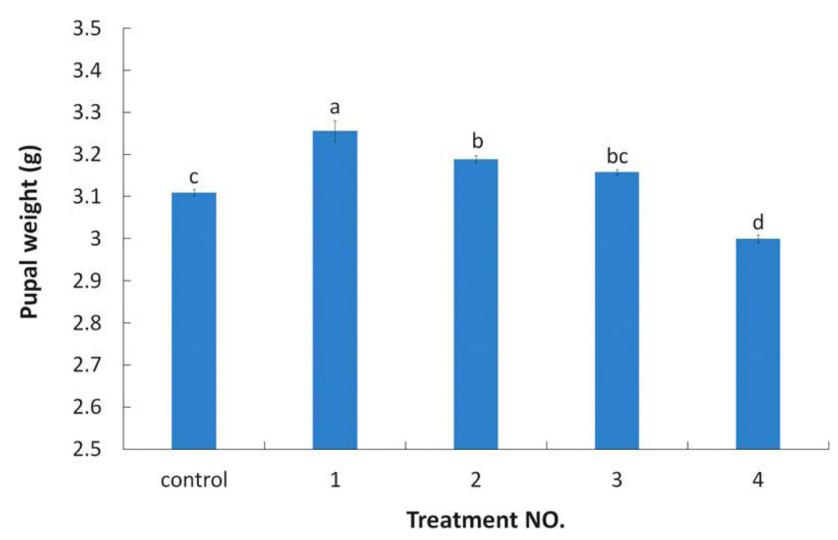

Fig. 5. The pupal weights of $D$. longicaudata recorded in each of the different temperature treatments. Each value is the mean $( \pm S E)$ of three replicates. Differences in the letters at the tops of the columns indicate significant difference at $P<0.05$ in ANOVA (Tukey test for multiple comparisons). 


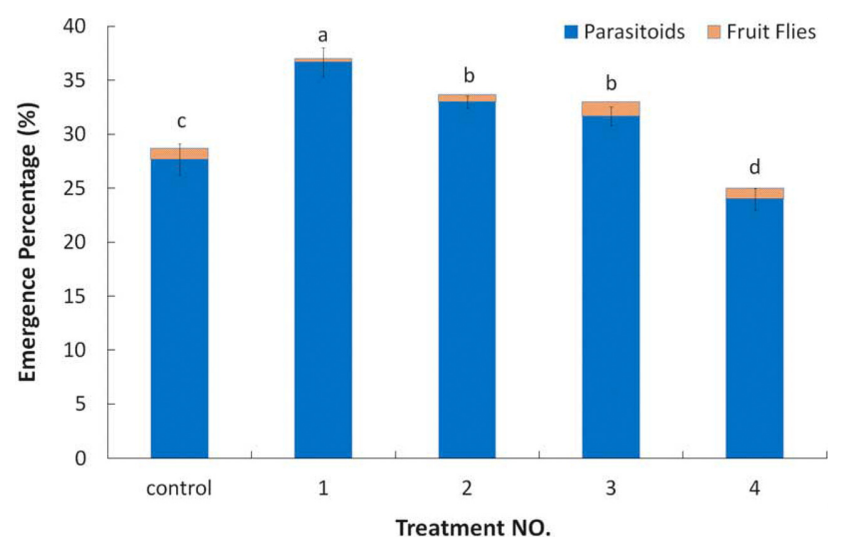

Fig. 6. Percentages of the parasitoid $D$. longicaudata and host $B$. dorsalis that emerged in each of the temperature treatments. Each value expresses the mean $( \pm S E)$ of three replications. Different letters topped on the bar mean significant difference at $\mathrm{P}<0.05$ in ANOVA (The percentage emergence of the parasitoid was subjected to Tukey test for multiple comparisons).

heat stress (Jia et al., 2011). In the present study, the activity of SOD was significantly higher at $31^{\circ} \mathrm{C} 24 \mathrm{~h}$ after parasitization than after the same period of time in any of the other temperature treatments. Moreover, the activity of SOD was significantly lower in the other temperature treatments compared with that recorded at $25^{\circ} \mathrm{C}$, probably because these unusual rearing temperatures suppressed the defensive antioxidant system of the cells, for example, by limiting the reduction of the superoxide radicals generated by ROS (Heck et al., 2003; Polte \& Tyrrell, 2004). SOD removes superoxide anions generated by increased mitochondrial activity by dismutation into oxygen and $\mathrm{H}_{2} \mathrm{O}_{2}$, and then the $\mathrm{H}_{2} \mathrm{O}_{2}$ is converted stepwise into water and oxygen (Abele et al., 1998; An \& Choi, 2010). Nevertheless, in our study, the levels of CAT were higher than that of SOD, which indicates that $\mathrm{H}_{2} \mathrm{O}_{2}$ was produced by other processes during thermal stress.

CAT is a light-sensitive antioxidant enzyme that is a crucial constituent of the insect antioxidant system; it is the sole enzyme responsible for converting $\mathrm{H}_{2} \mathrm{O}_{2}$ into water and oxygen because insects lack selenium-dependent glu-

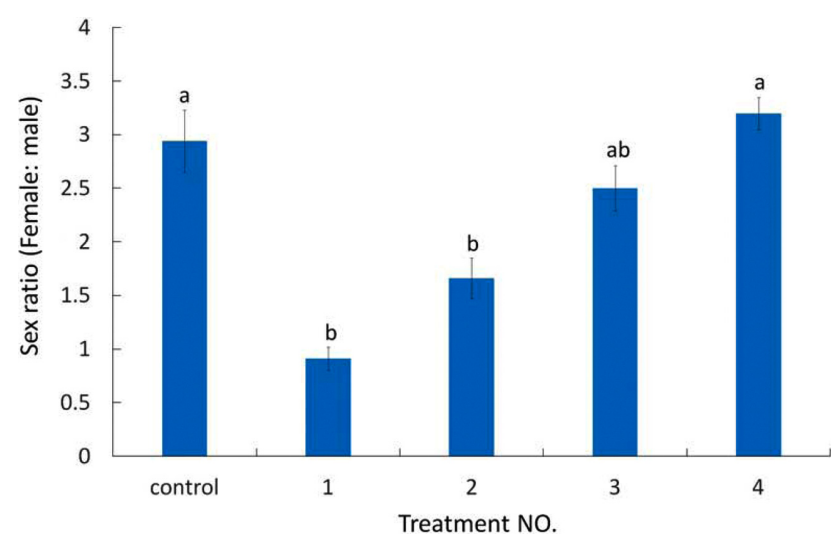

Fig. 7. The sex ratio of $D$. longicaudata recorded in each of the temperature treatments. Each value is the mean $( \pm S E)$ of three replicates. Differences in the letters at the tops of the columns indicate significant difference at $P<0.05$ in ANOVA (Tukey test for multiple comparisons).

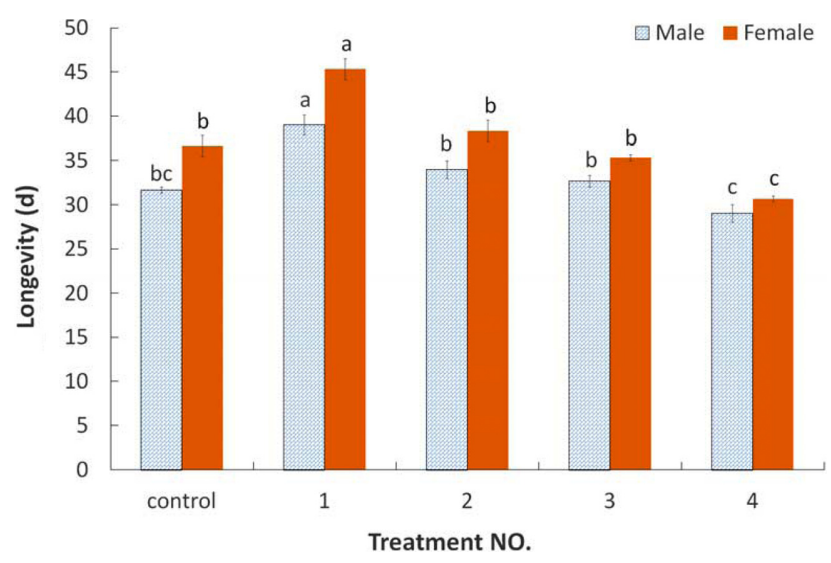

Fig. 8. The longevity of $D$. longicaudata recorded in each of the temperature treatments. Each value is the mean $( \pm S E)$ of three replicates. Differences in the letters at the tops on the columns indicate significant difference at $\mathrm{P}<0.05$ in log-rank test.

tathione peroxidase, which is a scavenger enzyme present in other organisms (Ahmad \& Pardini, 1990). CAT is directly regulated by the amount of $\mathrm{H}_{2} \mathrm{O}_{2}$ in a cell (Lesser, 2006). CAT efficiently eliminates $\mathrm{H}_{2} \mathrm{O}_{2}$ only at high cellular concentrations (Ahmad et al., 1991; Ahmad, 1992). CAT activity was lower after $4 \mathrm{~h}$ than after other intervals of time, therefore, it is likely that CAT scavenges $\mathrm{H}_{2} \mathrm{O}_{2}$ during the later stages of parasitization by $D$. longicaudata. Our results indicate that the activity of CAT in parasitized larvae of $B$. dorsalis increased after $48 \mathrm{~h}$ of exposure to high temperatures $\left(28,31^{\circ} \mathrm{C}\right)$, similar to the increased activity of SOD, as shown in Fig. 3. In addition, the overproduction of CAT at high temperatures resulted in an enhanced elimination of $\mathrm{H}_{2} \mathrm{O}_{2}$, thereby preventing oxidative damage. Earlier studies indicate that the expression of the CAT gene in Drosophila melanogaster is strongly correlated with longevity (Orr \& Sohal, 1994) and a reduction in the activity CAT or interruption in the expression of the CAT gene can result in death after emergence (Griswold et al., 1993; Orr \& Sohal, 1994).

POX is also responsible for breaking down of $\mathrm{H}_{2} \mathrm{O}_{2}$ in organisms and their high tolerance of stress (Lee et al., 2005). The highest activities of POX were recorded after 5 and $24 \mathrm{~h}$ in all temperature treatments except $31^{\circ} \mathrm{C}$, which may indicate that POX was mainly active after 5 and $24 \mathrm{~h}$. At $31^{\circ} \mathrm{C}$, a significant increase in the activity of POX was recorded after $24 \mathrm{~h}$ of exposure, whereas at $19^{\circ} \mathrm{C}$, there was a remarkable decline in the activity of POX $48 \mathrm{~h}$ after parasitization. A previous study reports that a negative feedback from excess substrate due to oxidative changes can decrease enzyme activity (Tabatabaie \& Floyd, 1994). The response of POX to changes in temperature deserve further evaluation.

A previous study reports that the eggs and larvae of parasitoids are more susceptible to temperature shocks than pupae (Firake \& Khan, 2014). Hence, we reared the immature stages of D. longicaudata under different temperature conditions in order to improve the effectiveness of this parasitoid by acclimatizing it to the variable environment it will experience in the field. We considered that the activ- 
ity of three major antioxidant enzymes (CAT, POX, SOD) indicates the ability of parasitized hosts to combat stresses and determined a preliminary temperature treatment strategy (see Table 2) for rearing $D$. longicaudata-infected $B$. dorsalis larvae. Due to parasitization by $D$. longicaudata, the developmental period of the larvae of $B$. dorsalis was prolonged to 5.5 days, which may be attributed to the different metabolic conditions (Wang \& Messing, 2003). Exposure to temperature treatment $1\left(4 \mathrm{~h}\right.$ at $28^{\circ} \mathrm{C}, 5$ and $48 \mathrm{~h}$ at $25^{\circ} \mathrm{C}, 49$ and $72 \mathrm{~h}$ at $31^{\circ} \mathrm{C}$ ) had a significantly positive effect on percentage of eggs that hatched, pupal weight, percentage emergence and parasitoid longevity compared with the constant temperature treatment. The lower percentage emergence recorded in the control and temperature treatment $2\left(48 \mathrm{~h}\right.$ at $25^{\circ} \mathrm{C}, 49$ and $72 \mathrm{~h}$ at $\left.31^{\circ} \mathrm{C}\right), 3$ ( $4 \mathrm{~h}$ at $25^{\circ} \mathrm{C}, 5$ and 24 at $28^{\circ} \mathrm{C}, 25$ and $72 \mathrm{~h}$ at $31^{\circ} \mathrm{C}$ ) and $4\left(24 \mathrm{~h}\right.$ at $25^{\circ} \mathrm{C}, 25$ and $72 \mathrm{~h}$ at $\left.31^{\circ} \mathrm{C}\right)$ might be due to a higher mortality of the immature stages of the parasitoid (Chihrane \& Laugé, 1996). The shrinkage or desiccation of host larvae may result in the development of weak and short lived parasitoids. Typically, well-fed parasitoids live longer than malnourished parasitoids (Reznik et al., 1997). Hence, it is likely that that stronger parasitoids will emerge from heavier pupae.

Varying the temperature conditions experienced by the immature stages had a significant effect on the sex ratio of the parasitoid, except in temperature treatment $4(24 \mathrm{~h}$ at $25^{\circ} \mathrm{C}, 25$ and $72 \mathrm{~h}$ at $31^{\circ} \mathrm{C}$ ). In this study, an undesirable male-biased sex ratio resulted when the immature parasitoids and their host larvae were exposed to temperature treatment $1\left(4 \mathrm{~h}\right.$ at $28^{\circ} \mathrm{C}, 5$ and $48 \mathrm{~h}$ at $25^{\circ} \mathrm{C}, 49$ and 72 $\mathrm{h}$ at $31^{\circ} \mathrm{C}$ ). It is likely that the temperature changes had a significant negative effect on the development of immature female parasitoids. Regardless of the undesirable sex ratio (female/male ratio below 1.00), temperature treatment 1 was accepted as the optimum temperature treatment for rearing immature parasitoids. However, the strong reduction in the number of females recorded in temperature treatment 1 is an important caveat.

A previous study indicates that species that perform well in the laboratory are more likely to do so in the field (Pak \& Lenteren, 1986). However, this study was done under laboratory conditions and the effects of changing the temperature during the immature development of the parasitoid on the performance of parasitoids in the field needs to be evaluated. Moreover, the connection between the activity of antioxidants in fruit fly larvae subject to stress, such as parasitization and changes in temperature, and the development of the parasitoid inside a host larva is poorly understood and needs further investigation. Our experiments aimed to provide guidance for improving the mass rearing of braconid parasitoids by varying the temperature at which they are reared.

ACKNOWLEDGEMENTS. We would like to thank S. Wang and C. Wang for rearing the D. longicaudata and B. dorsalis. This study was funded by the National Natural Science Foundation of China (NNSFC) No. 11175046.

\section{REFERENCES}

Abele D., Burlando B., Viarengo A. \& Pörtner H.O. 1998: Exposure to elevated temperatures and hydrogen peroxide elicits oxidative stress and antioxidant response in the Antarctic intertidal limpet Nacella concinna. - Comp. Biochem. Physiol. (B) 120: 425-435.

AHMAD S. 1992: Biochemical defence of pro-oxidant plant allelochemicals by herbivorous insects. - Biochem. Syst. Ecol. 20: 269-296.

Ahmad S. \& PARdini R.S. 1990: Mechanisms for regulating oxygen toxicity in phytophagous insects. - Free Radical Biol. Med. 8: 401-413.

Ahmad S., Duval D.L., Weinhold L.C. \& Pardini R.S. 1991: Cabbage looper antioxidant enzymes: tissue specificity. - Insect Biochem. 21: 563-572.

Ali A., Rashid M.A., Huang Q.Y. \& Lei C.L. 2017: Influence of UV-A radiation on oxidative stress and antioxidant enzymes in Mythimna separata (Lepidoptera: Noctuidae). — Environ. Sci. Pollut. Res. 24: 8392-8398.

Allwood A.J., Chinajariyawong A., Kritsaneepaiboon S., Drew R.A.I, Hamacek E.L., Hancock D.L., Hengsawad C., Jipanin J.C., Jirasurat M., Krong C.K., Leong C.T.S. \& Vijaysegaran S. 1999: Host plant records for fruit flies (Diptera: Tephritidae) in Southeast Asia. — Raffles B. Zool. 47: 1-92.

Aluja M., Sivinski J., Ovruski S., Guillén L., López M., Cancino J., Torres-Anaya A., Gallegos-Chan G. \& Ruíz L. 2009: Colonization and domestication of seven species of native new world hymenopterous larval-prepupal and pupal fruit fly (Diptera: Tephritidae) parasitoids. - Biocontrol Sci. Techn. 19: 49-79.

AN M.I. \& Chor C.Y. 2010: Activity of antioxidant enzymes and physiological responses in ark shell, Scapharca broughtonii, exposed to thermal and osmotic stress: effects on hemolymph and biochemical parameters. - Comp. Biochem. Phys. (B) 155: $34-42$.

Baranowski R., Glenn H. \& Sivinski J. 1993: Biological control of the Caribbean fruit fly (Diptera: Tephritidae). — Fla Entomol. 76: 245-251.

BRADFORD M.M. 1976: A rapid and sensitive method for the quantitation of microgram quantities of protein utilizing the principle of protein-dye binding. - Anal. Biochem. 72: 248-254.

Cai P.M., Gu X.H., Yao M.Y., Zhang H.H., Huang J., Idress A., JI Q.E., ChEn J.H. \& YANG J.Q. 2017: The optimal age and radiation dose for Bactrocera dorsalis (Hendel) (Diptera: Tephritidae) eggs as hosts for mass-reared Fopius arisanus (Sonan) (Hymenoptera: Braconidae). — Biol. Control 108: 89-97.

Cai P.M., Hong J.F., Wang C., Yang Y.C., Zhang Q.W., Ji Q.E. \& CHEN J.H. 2018a: Radiation of Bactrocera dorsalis (Diptera: Tephritidae) eggs to improve the mass rearing of Diachasmimorpha longicaudata (Hymenoptera: Braconidae). — J. Econ. Entomol. 111: 1157-1163.

Cai P.M., Hong J.F., Wang C., YANG Y.C., Yi C.D., Chen J.H. \& JI Q.E. 2018b: Effects of Co-60 radiation on the activities of three main antioxidant enzymes in Bactrocera dorsalis (Hendel) (Diptera: Tephritidae). — J. Asia-Pac. Entomol. 21: 345-351.

Carton Y., Poirié M. \& NAppi A.J. 2008: Insect immune resistance to parasitoids. - Insect Sci. 15: 67-87.

Chinrane J. \& LAUGÉ G. 1996: Loss of parasitization efficiency of Trichogramma brassicae (Hym.: Trichogrammatidae) under high-temperature conditions. — Biol. Control 7: 95-99.

Chinajariyawong A., Clarke A., Jirasurat M., Kritsaneepiboon S., Lahey H., Vijaysegaran S. \& Walter G. 2000: Survey of opiine parasitoids of fruit flies (Diptera: Tephritidae) in Thailand and Malaysia. — Raffles Bull. Zool. 48: 71-101. 
Clarke A.R., Allwood A., Chinajariyawong A., Drew R.A., Hengsawad C., Jirasurat M., Krong C.K., Kritsaneepaiboon S. \& ViJaysegaran S. 2001: Seasonal abundance and host use patterns of seven Bactrocera Macquart species (Diptera: Tephritidae) in Thailand and Peninsular Malaysia. - Raffles Bull. Zool. 49: 207-220.

Costa M.L.Z., Pacheco M.G., Lopes L.A., Botteon V.W. \& MasTRANGELO T. 2016: Irradiation of Anastrepha fraterculus (Diptera: Tephritidae) eggs to inhibit fly emergence in the massrearing of Diachasmimorpha longicaudata (Hymenoptera: Braconidae). - J. Insect Sci. 16: 1-9.

Dubovskiy I.M., Martemyanov V.V., Vorontsova Y.L., Rantala M.J., Gryzanova E.V. \& GLupov V.V. 2008: Effect of bacterial infection on antioxidant activity and lipid peroxidation in the midgut of Galleria mellonella L. larvae (Lepidoptera, Pyralidae). - Comp. Biochem. Phys. (C) 148: 1-5.

FIRAKE D.M. \& KHAN M.A. 2014: Alternating temperatures affect the performance of Trichogramma species. - J. Insect Sci. 14: $41,14 \mathrm{pp}$

Foyer C.H., Descourvieres P. \& Kunert K.J. 1994: Protection against oxygen radicals: an important defence mechanism studied in transgenic plants. - Plant Cell Environ. 17: 507-523.

Griswold C.M., Matthews A.L., Bewley K.E. \& Mahaffey J.W. 1993: Molecular characterization and rescue of acatalasemic mutants of Drosophila melanogaster. — Genetics 134: 781788 .

Heck D.E., Vetrano A.M., Mariano T.M. \& Laskin J.D. 2003 UVB light stimulates production of reactive oxygen species: unexpected role for catalase. - J. Biol. Chem. 278: 2243222436.

Ji Q.E., Bi K. \& Chen J.H. 2016: Response of egg-pupal parasitoid Fopius arisanus (Sonan) to infochemicals from the host eggs' surface of Bactrocera dorsalis (Hendel). — J. Asia-Pac. Entomol. 19: 1151-1157.

JIA F.X., Dou W., Hu F. \& WANG J.J. 2011: Effects of thermal stress on lipid peroxidation and antioxidant enzyme activities of oriental fruit fly, Bactrocera dorsalis (Diptera: Tephritidae). _ Fla Entomol. 94: 956-963.

Julsirikul D., Haymer D.S. \& Kitthawee S. 2017: Genetic structure and diversity of the Diachasmimorpha longicaudata species complex in Thailand: SSCP analysis of mitochondrial 16S rDNA and COI DNA sequences. - Biochem. Syst. Ecol. 71: 59-68.

Lee K.S., Kim S.R., Park N.S., Kim I., Kang P.D., Sohn B.H., Choi K.H., Kang S.W., Je Y.H., Lee S.M., Sohn H.D. \& JiN B.R. 2005: Characterization of a silkworm thioredoxin peroxidase that is induced by external temperature stimulus and viral infection. - Insect Biochem. Mol. Biol. 35: 73-84.

LESSER M.P. 2006: Oxidative stress in marine environments: biochemistry and physiological ecology. - Annu. Rev. Physiol. 68: $253-278$.

Liang G.H., ChEN Y.R. \& Huang J.C. 2007: Effects of parasitism on the activity of peroxidase in the larvae of Bactrocera dorsalis (Diptera: Tephritidae). — J. Cent. South Univ. For. Techn. 27: 48-51.

Lin L., Huang J.C., Chen J.H., Ji Q.E. \& Yang J.Q. 2006: Parasitical efficiency of Diachasmimorpha longicaudata on Bactrocera dorsalis. - Entomol. J. East China 15: 288-290.

Liu C.Y., ChEN K.W. \& ZENG L. 2012: Effects of temperature on the development and fecundity of Diachasmimorpha longicaudata (Ashmead). — Chin. J. Appl. Ecol. 23: 3051-3056.

LivingSTONE D.R. 2001: Contaminant-stimulated reactive oxygen species production and oxidative damage in aquatic organisms. — Mar. Poll. Bull. 42: 656-666.
Lopez-Martinez G., Elnitsky M.A., Benoit J.B., Lee R.E. \& DeNLINGER D.L. 2008: High resistance to oxidative damage in the Antarctic midge Belgica antarctica, and developmentally linked expression of genes encoding superoxide dismutase, catalase and heat shock proteins. - Insect Biochem. Mol. Biol. 38: 796-804.

LuCK H. 1971: Bergmeyer H.U. (ed.): Catalase. Methods of Enzymatic Analysis. Academic Press, New York, pp. 885-893.

Maceda A., Hohmann C.L. \& Santos H.R. 2003: Temperature effects on Trichogramma pretiosum Riley and Trichogrammatoidea annulata de Santis. - Braz. Arch. Biol. Techn. 46: 27-32.

Mannino M.C., Rivarola M., Scannapieco A.C., González S., Farber M., Cladera J.L. \& Lanzavecchia S.B. 2016: Transcriptome profiling of Diachasmimorpha longicaudata towards useful molecular tools for population management. BMC Genomics 17: 793, 13 pp.

MARKLUND S. \& MARKLUND G. 1974: Involvement of the superoxide anion radical in the autoxidation of pyrogallol and a convenient assay for superoxide dismutase. - Eur. J. Biochem. 47: 469-474.

Meirelles R.N., Redaelli L.R. \& Ourique C.B. 2013: Comparative biology of Diachasmimorpha longicaudata (Hymenoptera: Braconidae) reared on Anastrepha fraterculus and Ceratitis capitata (Diptera: Tephritidae). — Fla Entomol. 96: 412-418.

Meirelles R.N., Redaelli L.R. \& Ourique C.B. 2015: Thermal requirements and annual number of generations of Diachasmimorpha longicaudata (Hymenoptera: Braconidae) reared in the South American fruit fly and the Mediterranean fruit fly (Diptera: Tephritidae). — Fla Entomol. 98: 1223-1226.

Nolela S., Mohamed S., Ndegwa P.N., Ongama G. \& Ekesi S. 2016: Release, establishment and dispersal of Diachasmimorpha longicaudata (Ashmead) and Fopius arisanus (Sonan): Hymenoptera: Braconidae, for the management of Bactrocera dorsalis in Kenya. In: Abstracts. Tephritid Workers of Europe, Africa and the Middle East (TEAM 2016), 3rd International Symposium, 11-14 April 2016, Stellenbosch, South Africa.

ORR W.C. \& SoHAL R.S. 1994: Extension of life-span by overexpression of superoxide dismutase and catalase in Drosophila melanogaster. - Science 263: 1128-1130.

PAK G.A. \& VAN Lenteren J.C. 1986: Criteria and methods for the prerelease evaluation of different Trichogramma spp. strains. In Voegele J., Waage J. \& Van Lenteren J. (eds): Trichogramma and Other Egg Parasites. 2nd International Symposium, INRA, Guangzhou, China, 10-15 November 1986. pp. 433-441.

Park M.S., Jo P.G., Chol Y.K., AN K.W. \& Chol C.Y. 2009: Characterization and mRNA expression of Mn-SOD and physiological responses to stresses in the Pacific oyster Crassostrea gigas. - Mar. Biol. Res. 5: 451-461.

Polte T. \& Tyrrell R.M. 2004: Involvement of lipid peroxidation and organic peroxides in UVA-induced Matrix Metalloproteinase-1 expression. - Free Rad. Biol. Med. 36: 1566-1574.

Reddy K.P., Subhani S.M., Khan P.A. \& Kumar K.B. 1985: Effect of light and benzyladenine on dark-treated growing rice (Oryza sativa) leaves II. Changes in peroxidase activity. Plant Cell Physiol. 26: 987-994.

Reznik S.Y., Umarova T.Y. \& VoInovich N.D. 1997: The influence of previous host age on current host acceptance in Trichogramma. - Entomol. Exp. Appl. 82: 153-157.

Segura D.F., Nussenbaum A.L., Viscarret M.M., Devescovi F., Bachmann G.E., Corley J.C., Ovruski S.M. \& Cladera J.L. 2016: Innate host habitat preference in the parasitoid Diachasmimorpha longicaudata: functional significance and modifications through learning. - PLOS ONE 11: e0152222, 18 pp. 
Shao T., Liu C.Y., Chen K.W. \& Zeng L. 2008: Mass-rearing methods of Bactrocera dorsalis (Diptera: Tephritidae) and itslarval-pupal parasitoid Diachasmimorpha longicaudata (Hymenoptera: Braconidae). - J. Environ. Entomol. 30: 377-380.

Simmonds T.J., Carrillo D. \& Burke G.R. 2016: Characterization of a venom gland-associated rhabdovirus in the parasitoid wasp Diachasmimorpha longicaudata. - J. Insect Physiol. 91-92: 48-55.

SPENCER J.P. \& FUJITA B.H. 1997: A Procedural Manual for Mass Rearing Four Species of Tephritid Fruit Flies. U.S. Department of Agriculture, Anaesthetics Research Society, Honolulu, HI.

TABATABAiE T. \& Floyd R.A. 1994: Susceptibility of glutathione peroxidase and glutathione reductase to oxidative damage and the protective effect of spin trapping agents. - Arch. Biochem. Biophys. 314: 112-119.

Vargas R.I., Stark J.D., Uchida G.K. \& Purcell M. 1993: Opiine parasitoids (Hymenoptera: Braconidae) of oriental fruit fly (Diptera: Tephritidae) on Kauai Island, Hawaii: islandwide relative abundance and parasitism rates in wild and orchard guava habitats. - Environ. Entomol. 22: 246-253.

Vargas R.I., Leblanc L., Putoa R. \& Eitam A. 2007: Impact of introduction of Bactrocera dorsalis (Diptera: Tephritidae) and classical biological control releases of Fopius arisanus (Hymenoptera: Braconidae) on economically important fruit flies in French Polynesia. - J. Econ. Entomol. 100: 670-679.

Vargas R.I., Leblanc L., Harris E.J. \& Manoukis N.C. 2012: Regional suppression of Bactrocera fruit flies (Diptera: Tephritidae) in the pacific through biological control and prospects for future introductions into other areas of the world. - Insects 3: $727-742$.

Wang X.G. \& Messing R.H. 2003: Intra- and interspecific competition by Fopius arisanus and Diachasmimorpha tryoni (Hy- menoptera: Braconidae), parasitoids of tephritid fruit flies. Biol. Control 27: 251-259.

WANG Y., Guo J.J., ChEN J.H. \& JI Q.E. 2013: The changes of the activity of four enzymes in larvae of Bactrocera dorsalis (Hendel) parasitized by Diachasmimorpha longicaudata. - Chin. J. Trop. Crops 34: 335-338.

Wharton R.A. \& Gilstrap F.E. 1983: Key to and status of opiine braconid (Hymenoptera) parasitoids used in biological control of Ceratitis and Dacus s. 1. (Diptera: Tephritidae). - Ann. Entomol. Soc. Am. 76: 721-742.

Wong T.T.Y., Ramadan M.M., Anderson T.E. \& Leppla N.C. (eds) 1992: Mass Rearing Biology of Larval Parasitoids (Hymenoptera: Braconidae) of Tephritid Fruit Flies in Hawaii. Advances in Insect Rearing for Research and Pest Management. Westview Press, Boulder, CO, pp. 405-476.

Yang L.H., Huang H. \& Wang J.J. 2010: Antioxidant responses of citrus red mite, Panonychus citri (McGregor) (Acari: Tetranychidae), exposed to thermal stress (Acari: Tetranychidae). -J. Insect Physiol. 56: 1871-1876.

Yang J.Q., Cai P.M., Chen J., Zhang H.H., Wang C., Xiang H.J., Wu J., Yang Y.C., Chen J.H., Ji Q.E. \& Song D.B. 2018: Interspecific competition between Fopius arisanus and Psyttalia incisi (Hymenoptera: Braconidae), parasitoids of Bactrocera dorsalis (Diptera: Tephritidae). — Biol. Control 121: 183-189.

ZAR J.H. 1984: Biostatistical Analysis. Englewood Cliffs, Prentice-Hall, NJ, 718 pp.

Zhang R.M., He S.Y. \& Chen J.H. 2014: Monitoring of Bactrocera dorsalis (Diptera: Tephritidae) resistance to Cyantraniliprole in the south of China. - J. Econ. Entomol. 107: 1233-1238.

Received February 23, 2018; revised and accepted November 20, 2018 Published online January 4, 2019 